\title{
FEATURE Using enhanced wetlands for nitrogen removal in an agricultural watershed
}

\author{
Anna Fehling, Steve Gaffield, and Stephen Laubach
}

$\mathrm{E}$

xcess nitrogen $(\mathrm{N})$ in temperate watersheds has been associated with an array of environmental problems, including polluted wells and surface water. The hypoxic zone in the Gulf of Mexico has created a particular focus on $\mathrm{N}$ loads in the Mississippi River Basin. Nitrogen sources include urban runoff; atmospheric deposition; point sources, such as wastewater treatment plants; and nonpoint sources, such as runoff from agricultural lands. Approximately two-thirds of the $\mathrm{N}$ load of the Mississippi River is from agriculture, underscoring the importance of balancing productive farming with water quality improvement (Goolsby and Battaglin 2000).

Wetland restoration has been identified as a strategy with the potential to reduce watershed $\mathrm{N}$ loads. Slowly moving water, high microbial activity, and long residence times can create low dissolved oxygen $\left(\mathrm{O}_{2}\right)$ conditions under which bacteria convert nitrate $\left(\mathrm{NO}_{3}\right)$ to $\mathrm{N}$ gas in shallow water wetlands (Kadlec and Knight 1996). This denitrification processs physically removes $\mathrm{N}$ in the form of inert $\mathrm{N}$ gas from the aquatic system (Hey et al. 2012). Forshay and Stanley (2005) documented rapid denitrification in wetland sloughs on the Wisconsin River floodplain, where $\mathrm{NO}_{3}$ concentrations in floodwater captured by overbank flow into the sloughs decreased significantly over a few days.

This paper presents an example of an enhanced wetland designed to reduce $\mathrm{N}$ loads from active farmland adjacent to the Leopold Memorial Reserve and the Wisconsin River in south-central Wisconsin. Funded by a grant from the Natural Resources Conservation Service (NRCS) to Sand County Foundation, it involves collaboration between Sand

Anna Fehling is a water resources engineer with Montgomery Associates: Resource Solutions in Cottage Grove, Wisconsin. Steve Gaffield is a hydrologist with Montgomery Associates: Resource Solutions in Cottage Grove, Wisconsin. Stephen Laubach is an agricultural incentives consultant with Sand County Foundation in Madison, Wisconsin.
County Foundation and Montgomery Associates: Resource Solutions, LLC. The reserve is home to Aldo Leopold's famous shack and is the setting for Part I of $A$ Sand County Almanac (Laubach 2014). Extensive research on floodplain dynamics has been conducted there over the past three decades (Hunt 1987; Zolidis 1987; Freeman et al. 2003). The goal of this project was to create a monitored demonstration of a simple wetland enhancement that reduces $\mathrm{N}$ loads, fits into a working agricultural landscape, and could be easily replicated on other farms.

\section{SITE SELECTION AND ASSESSMENT}

The project site selection was primarily opportunistic-Sand County Foundation owns the property and has a long-term relationship with the farmer working the land. The site was a degraded wetland located adjacent to a drainage ditch carrying agricultural runoff and was not being actively used.Vegetation in the wetland was dominated by invasive reed canarygrass (Phalaris arundinacea L.). Approximately $14.2 \mathrm{~km}^{2}\left(5.5 \mathrm{mi}^{2}\right)$ of agricultural land south of Interstate 90/94 flow to a drainage ditch that traverses the project site and ultimately empties into the Wisconsin River to the north (figure 1). Although the

\section{Figure 1}

Map of site location in south-central Wisconsin with close-up of watershed drained by ditch.

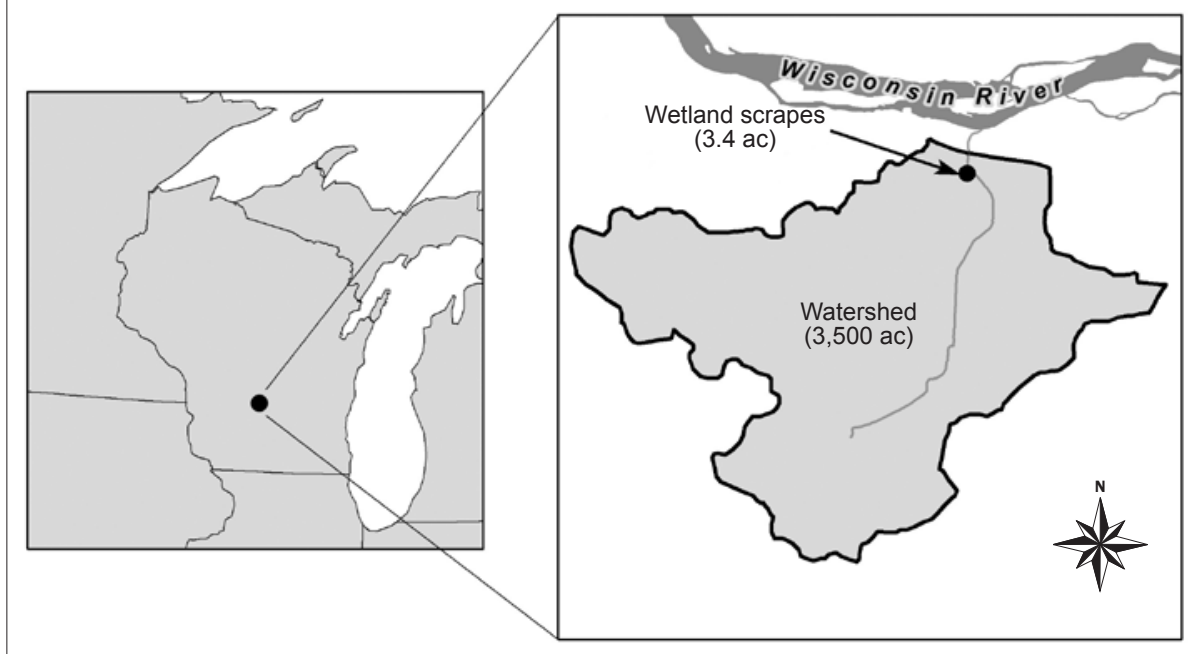

site is small compared to the watershed, the goal of the project is to demonstrate an effective means of reducing $\mathrm{N}$ load that could be widely employed at a variety of scales using available space.

Initial monitoring of the Leopold Memorial Reserve site was conducted beginning in 2009 to guide the conceptual and final design of the wetland scrapes. Data collection included soil exploration, continuous water level monitoring and water quality analysis of groundwater and local surface water, and a wetland delineation. Additionally, a review of aerial photographs and discussions with local farmers provided insights on historic flooding extent and frequency. It was determined that high flows overtopped the ditch banks and inundated the wetland several times per year, providing an opportunity to capture and treat some of this water.

\section{WETLAND ENHANCEMENT DESIGN AND CONSTRUCTION}

At the project's outset in 2009, three design approaches were considered: (1) creating shallow ponds within the ditch that would flood and drain slowly during rain events; (2) restoring and expanding a wetland adjacent to the ditch to treat overland flow only; and (3) restoring and expanding a wetland 


\section{Figure 2}

(a) Layout of wetland with arrows indicating direction of flow and berm design, and north scrape (b) during and (c) after construction.

(a)

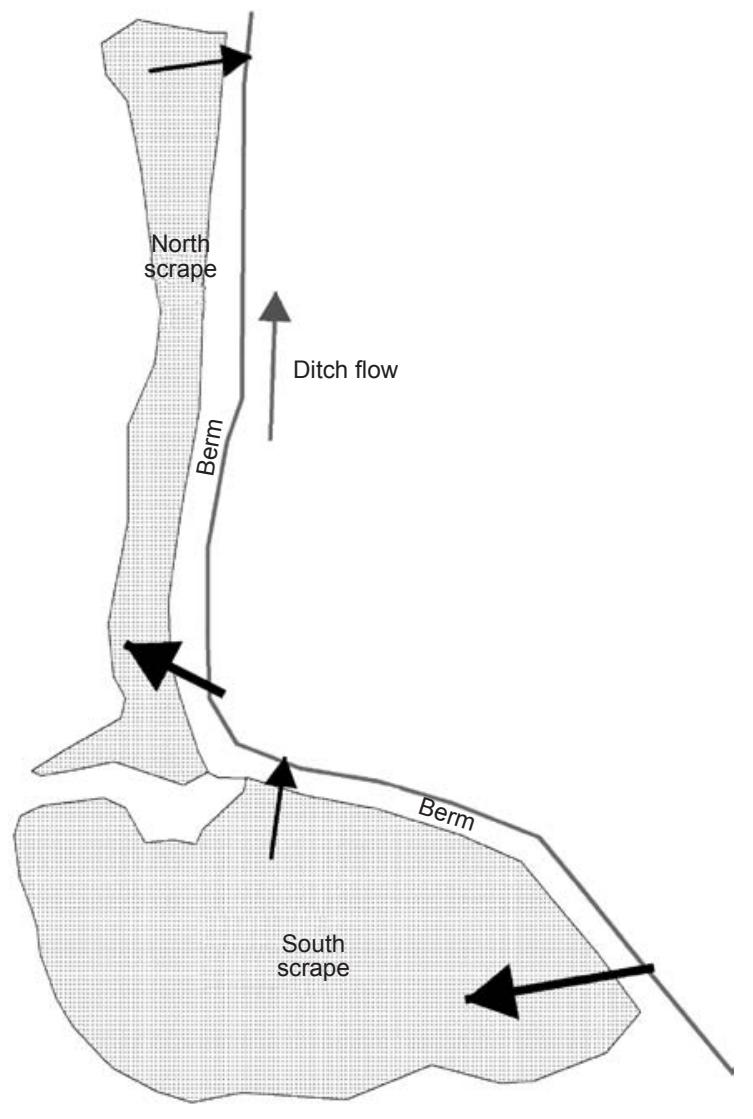

(b)

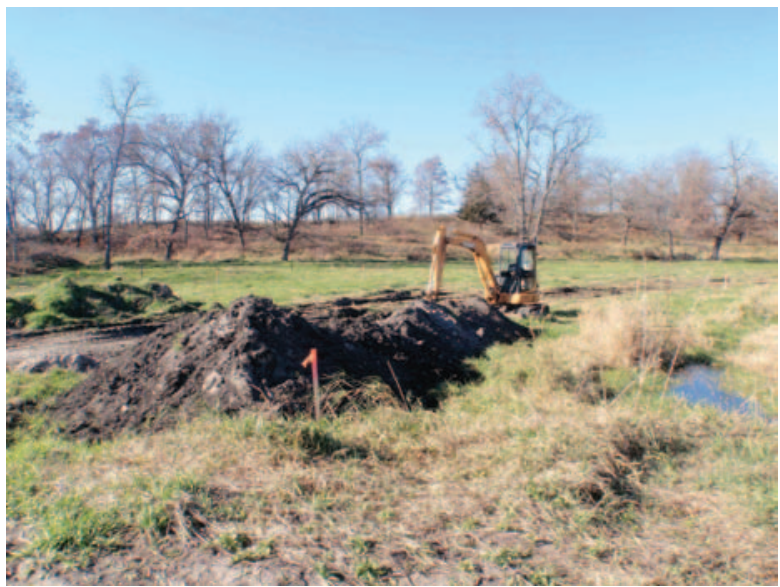

(c)

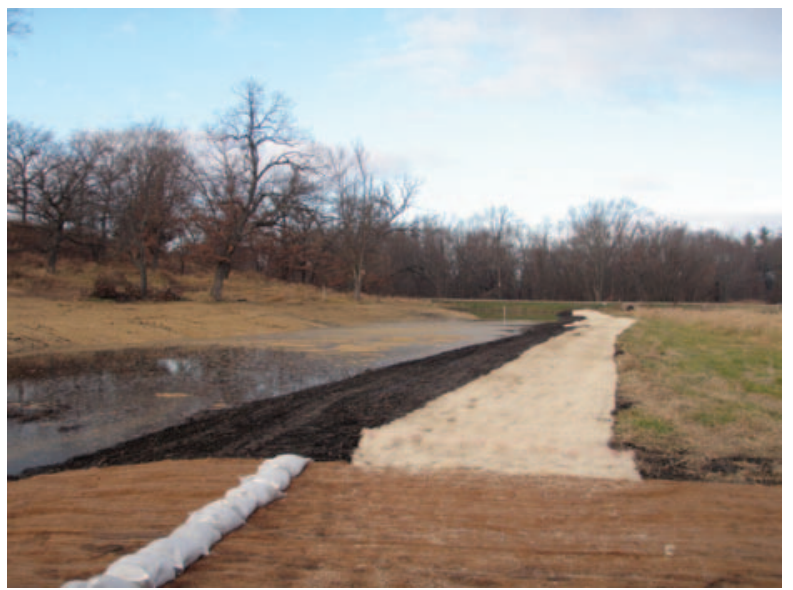

parallel to the ditch that is connected to it only during high water events.

A hydrologic and hydraulic analysis of the site was completed to evaluate the design alternatives. Runoff volume and discharge to the wetland site were estimated using standard NRCS runoff curve number methods. A rainfall-runoff model was constructed for the upstream watershed using the XP-SWMM storm water management model to simulate storm runoff in the ditch on the property for storms of different recurrence intervals.

The potential impact of alternative wetland designs on upstream flood elevations was evaluated through construction of a hydraulic model of the ditch and proposed wetland using Hydrologic Engineering Centers River Analysis System (HEC-RAS). Simulations were conducted for existing conditions and several alternative wetland designs to evaluate impacts on the 100-year flood elevation and on smaller, more frequent floods, such as the 1-year and 10-year events.

Sand County Foundation and Montgomery Associates ultimately decided on the third option (restoring and expanding a wetland parallel to the ditch) for several reasons. First, it was the simplest for which to receive approval from the Wisconsin Department of Natural Resources. Second, project managers concluded that this design was simplest not only for regulatory approval but also for scalability. Unlike the first option, the ease of permitting and design makes the project easier to replicate. Finally, this design would capture and treat significantly more runoff than the second option, with nominal additional effort. It was agreed upon that other farmers attempting to reduce $\mathrm{N}$ inputs would find this model replicable and affordable.

In late 2010, two scrapes totaling 1.4 ha $(3.4 \mathrm{ac})$ were constructed to enhance the existing wetland area. These two shal- low excavations temporarily pond water that overflows the ditch during large rainfalls (figure 2). To increase the temporary floodwater storage of the wetland, a low berm was constructed between the scrapes and the ditch, with multiple overflow points to allow floodwaters to spill laterally from the ditch into the scrapes. The intent of the design is to capture ditch overflow several times per year and to retain water in the scrapes long enough for denitrification to occur, similar to the nearby floodplain sloughs studied by Forshay and Stanley (2005). Between rainfalls, ponded water drains out of the wetland through infiltration and evapotranspiration.

Implementation issues included coping with varying climactic conditions and impacts of construction while maintaining the function of the wetland scrapes. Consecutive wet and dry years presented a challenge for establishing vegetation. 
Compaction of soil by construction equipment additionally reduced the intended groundwater connection to the scrapes, thereby increasing ponding duration. A major flood on the Wisconsin River caused backwater flooding of the wetland in 2010. The compacted soils and high groundwater caused one scrape to hold the 2010 floodwaters for over a year, preventing the establishment of any vegetation in the ponded area. Vegetation establishment was further set back by the drought of 2012 . After the drought, the soil in the scrapes was dry enough to till, which has enhanced infiltration of water and allowed vegetation establishment. Native wetland grasses and forbs have been gradually established with the mix of native species selected to balance ecological function and visual appeal. Vegetation has been maintained by scheduled burning, mowing, and spot herbicide treatments of invasive species (figure 3 ).

\section{MONITORING DATA}

Monitoring focused on characterizing the nutrient load in the agricultural ditch and the fate of $\mathrm{N}$ in the wetlands. Following construction and seeding, initial data collection primarily consisted of characterizing the nutrient load in the ditch. Data collection included continuous flow monitoring and automated water quality sampling of $\mathrm{N}$, chloride $(\mathrm{Cl})$, phosphorus $(\mathrm{P})$, and total suspended solids. Background data were also collected on precipitation, groundwater and surface water quality, and water levels.

After an unusually dry preceding year, rainfall in 2013 rose to $76.94 \mathrm{~cm}(30.29$ in), close to the long-term annual average of $86.1 \mathrm{~cm}$ (33.9 in). The scrapes received overflow from the ditch seven times between March and June of 2013, meeting the intended design of receiving ditch inflow several times per year.

Load characterization data indicate that this tributary has relatively low $\mathrm{N}$ loading compared to adjacent areas. This could reflect denitrification that may occur in two large wetlands upstream of the project site or differences in nutrient management between watersheds. In 2013, a year of approximately average precipitation, the total annual $\mathrm{N}$ yield was $7,711 \mathrm{~kg}(17,000 \mathrm{lb})$, or $5.6 \mathrm{~kg}$ $\mathrm{ha}^{-1}\left(5 \mathrm{lb} \mathrm{ac}^{-1}\right)$ of watershed. This is low compared to typical values for nutrient-rich agricultural watersheds that have reported yields of $6.7 \mathrm{~kg} \mathrm{ha}^{-1}\left(6 \mathrm{lb} \mathrm{ac}^{-1}\right)$ to as much as $100.9 \mathrm{~kg} \mathrm{ha}^{-1}\left(90 \mathrm{lb} \mathrm{ac}^{-1}\right.$ ) (Mitsch et al. 1999; USGS 1999; Schilling and Lutz 2004). The load in the severe drought of 2012 was $3 \mathrm{~kg} \mathrm{ac}^{-1}\left(2.7 \mathrm{lb} \mathrm{ac}^{-1}\right)$, a result of diminished runoff volume. In both years, the $\mathrm{N}$ load in the ditch was primarily driven by snowmelt and large rain events (figure 4). Because the scrapes received ditch overflow only during the larger runoff events, they are effectively treating the nutrient load at the times of highest load release.

Following two years of monitoring to gain an understanding of general ecological function, data collection efforts shifted to an evaluation of $\mathrm{N}$ removal in the scrapes, including water quality grab sampling and an analysis of overflow volume and frequency. The intent of the monitoring was to gauge the potential for this and other similar projects to reduce excess $\mathrm{N}$ in the Mississippi River Basin and its tributaries.

Water quality grab sampling in the scrapes following overflow events showed $\mathrm{NO}_{3}$ concentrations decreased to undetectable levels within two to four days (figure 5). By comparison, $\mathrm{NO}_{3}$ concentrations in the ditch remained high during the same period. Groundwater $\mathrm{NO}_{3}$ also remained low, suggesting that $\mathrm{NO}_{3}$ did not leach into the water table. These data indicate that the scrapes removed at least $113 \mathrm{~kg} \mathrm{~N} \mathrm{ha}^{-1}\left(100 \mathrm{lb} \mathrm{N} \mathrm{ac}^{-1}\right)$ of wetland from the watershed in 2013.

\section{CONCLUSIONS}

Preliminary results show that this simple wetland enhancement in an area that was not being actively farmed results in measurable $\mathrm{N}$ load reduction. The project balances simplicity (e.g., no moving parts) with enough understanding of the watershed and wetland hydrology to develop a design that can effectively remove $\mathrm{N}$ from the watershed. We therefore believe that this type of project has potential for widespread adoption as a simple, low-cost strategy to reduce nutrient inputs to the Mississippi River and other water bodies.

Monitoring is continuing and will be adjusted based on results to date. For example, to verify that anoxic conditions needed for denitrification are present, future monitoring will include testing for dissolved $\mathrm{O}_{2}$ in the scrapes.Additionally, the wetland soil will be sampled to evaluate storage of nutrients.

Similar projects would benefit from a review of site conditions. Site selection and layout should consider existing land use,

\section{Figure 3}

(a) South scrape and (b) north scrape after vegetation establishment.

(a)

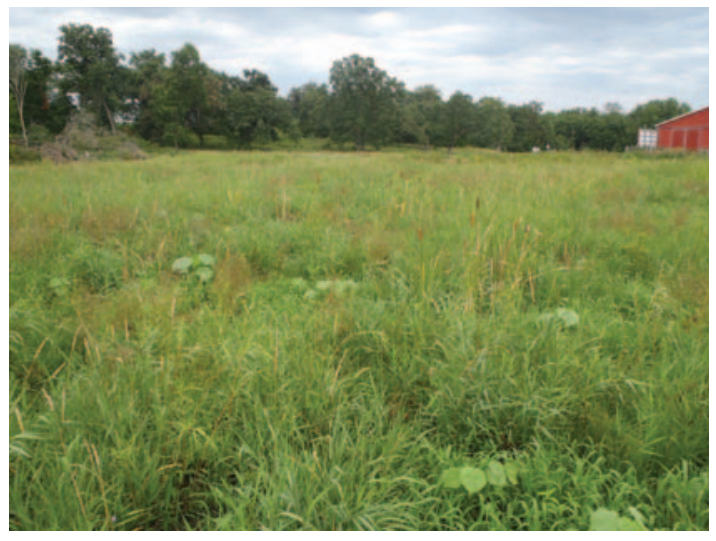

(b)

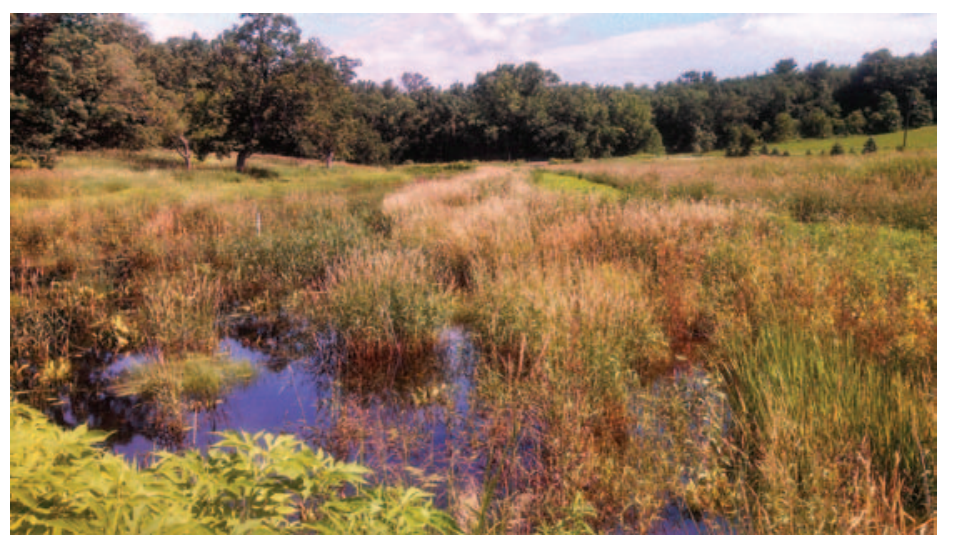


proximity to a ditch, topography, and ease of overflow to the scrapes. If desired, a much more thorough analysis can be conducted as was done on this project site. Data to support a detailed study would include local weather patterns, topography, soil type, subsurface hydrology, and other watershed characteristics. The hydrology and nutrient cycling in the wetland should be understood well enough to design a wetland enhancement or restoration that is likely to meet the desired water quality objectives. This includes estimates of the volume and frequency of flows into the wetland and the residence time in the wetland, and an understanding of the nutrient cycling processes that are likely to occur. The monitoring approach used in this project could easily be adapted to track the cycling of other chemical constituents of interest.

As noted by Penn et al. (2014), largescale adoption of nutrient removal practices depends largely on cost. Nonpoint source nutrient impacts are still for the most part external to the market. Government investment aimed at lowering early adoption risk can provide the necessary incentive for implementation. For longterm success, Penn et al. also emphasize the need for market innovations such as nutrient abatement trading. Together, these approaches would provide lasting incentives for farmers to reduce nutrient inputs to area waterways. Participating farms in this scenario would be one step closer to Aldo Leopold's call for improved conservation practices on private property.

\section{REFERENCES}

Forshay, K.J., and E.H. Stanley. 2005. Rapid nitrate loss in a temperate river floodplain. Biogeochemistry 75:43-64.

Freeman, R.E., E.H. Stanley, and M.G. Turner. 2003. Landscape change in the Wisconsin River floodplain, USA. Ecological Applications 13:416-431.

Goolsby, D.A., and W.A. Battaglin. 2000. Nitrogen in the Mississippi Basin: Estimating sources and predicting flux to the Gulf of Mexico. US Geological Survey Fact Sheet 135-00. Reston, VA: US Geological Survey.

Hey, D.L., J.A. Kostel, W.G. Crumpton, W.J. Mitsch, and B. Schott. 2012. The roles and benefits of wetlands in managing reactive nitrogen. Journal of Soil and Water Conservation 67(2):47A-53A, doi:10.2489/jswc.67.2.47A.

Hunt, R.J.1987.A Survey of the Hydrogeochemistry of the Leopold Memorial Reserve,Baraboo,Wisconsin. Master's thesis, University of Wisconsin-Madison.

\section{Figure 4}

Ditch flow and cumulative nitrogen $(\mathrm{N})$ load in 2013. The dashed flow line indicates where continuous data was not available due to ice or low water levels. Flow for these periods was estimated from manual flow measurements, water levels, and precipitation data.

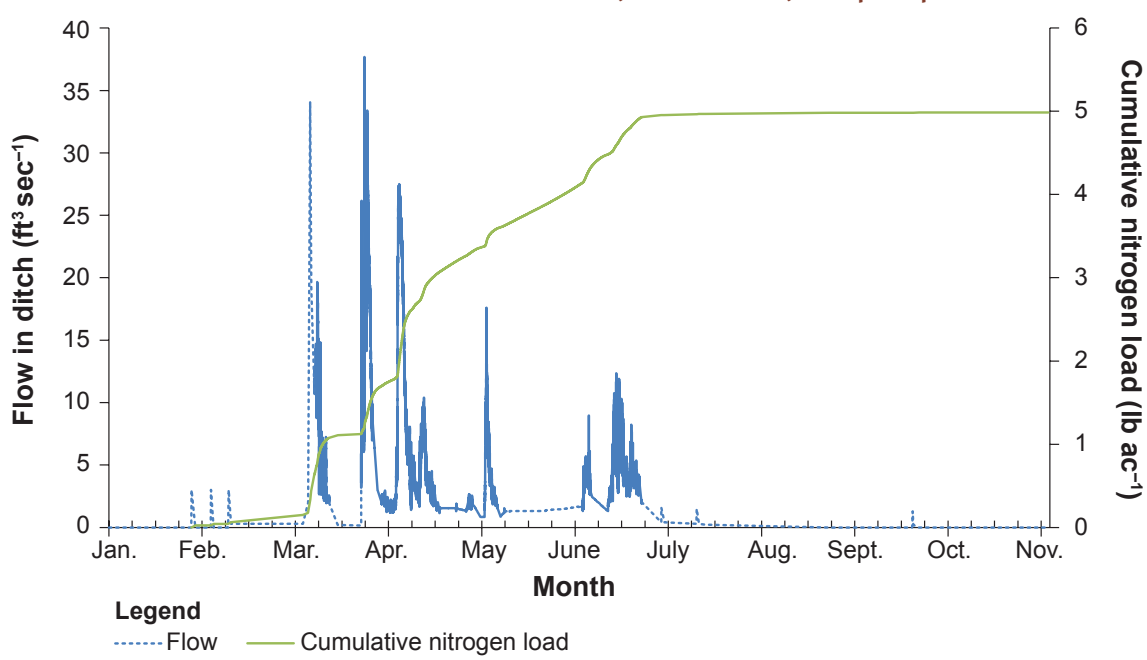

\section{Figure 5}

Ditch stage and wetland nitrate $\left(\mathrm{NO}_{3}\right)$ concentration after typical rain event.

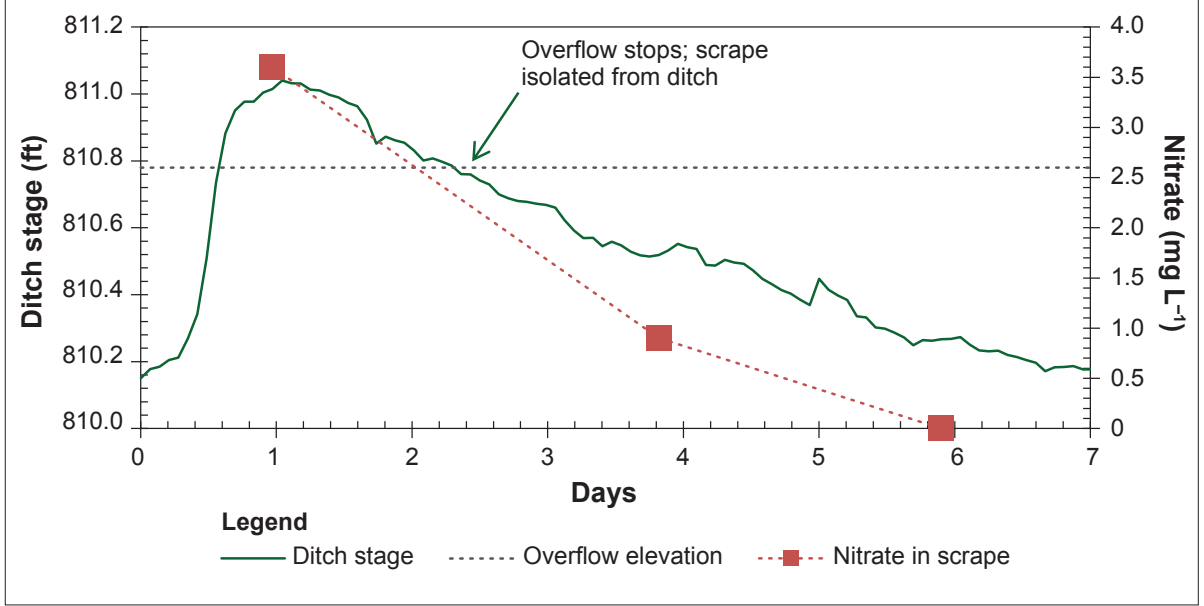

Kadlec, R.H., and R.L. Knight. 1996. Treatment Wetlands. Boca Raton: Lewis Publishers.

Laubach, S.A. 2014. Living a Land Ethic: A History of Cooperative Conservation on the Leopold Memorial Reserve. Madison: University of Wisconsin Press.

Mitsch, W.J., J.W. Day, Jr., J.W. Gilliam, P.M. Groffman, D.L. Hey, G.W. Randall, and N. Wang. 1999. Reducing nutrient loads, especially nitratenitrogen, to surface water, ground water, and the Gulf of Mexico: Topic 5 report for the integrated assessment of hypoxia in the Gulf of Mexico. National Oceanic and Atmospheric Association Coastal Ocean Program Decision Analysis Series No. 19. Silver Spring, MD: National Oceanic and Atmospheric Association Coastal Ocean Program.
Penn, C., J. McGrath, J. Bowen, and S. Wilson. 2014. Phosphorus removal structures: A management option for legacy phosphorus. Journal of Soil and Water Conservation 69(2):51A-56A, doi:10.2489/jswc.69.2.51A.

Schilling, K.E., and D.S. Lutz. 2004. Relation of nitrate concentrations to baseflow in the Raccoon River, IA. Journal of the American Water Resources Association 40(4):889-900.

US Geological Survey. 1999. The quality of our nation's waters-nutrients and pesticides. US Geological Survey Circular 1225. Reston, VA: US Geological Survey.

Zolidis, N.R. 1987. The Hydrogeology of the Leopold Memorial Reserve. Master's thesis, University of Wisconsin-Madison. 